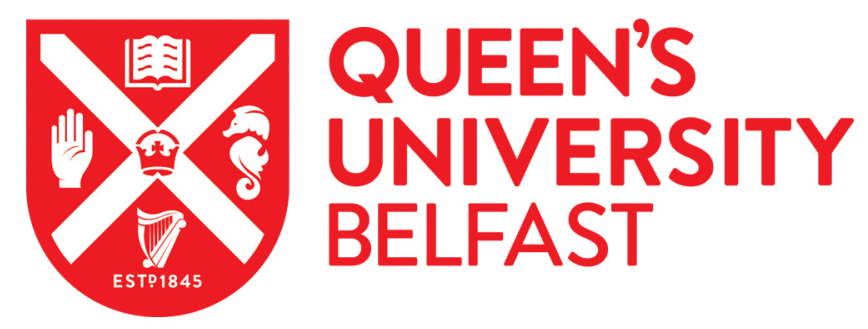

\title{
Ritual, identity and nation: when the historian becomes the high priest of commemoration
}

Bryan, D. (2016). Ritual, identity and nation: when the historian becomes the high priest of commemoration. In R. Grayson, \& F. McGarry (Eds.), Remembering 1916 The Easter Rising, the Somme and the Politics of Memory in Ireland (pp. 24-42). Cambridge University Press .

Published in:

Remembering 1916 The Easter Rising, the Somme and the Politics of Memory in Ireland

Document Version:

Early version, also known as pre-print

Queen's University Belfast - Research Portal:

Link to publication record in Queen's University Belfast Research Portal

Publisher rights

(c) 2016 The Author

\section{General rights}

Copyright for the publications made accessible via the Queen's University Belfast Research Portal is retained by the author(s) and / or other copyright owners and it is a condition of accessing these publications that users recognise and abide by the legal requirements associated with these rights.

Take down policy

The Research Portal is Queen's institutional repository that provides access to Queen's research output. Every effort has been made to ensure that content in the Research Portal does not infringe any person's rights, or applicable UK laws. If you discover content in the Research Portal that you believe breaches copyright or violates any law, please contact openaccess@qub.ac.uk. 


\section{Ritual, Identity and Nation: When the historian becomes the high priest of Commemoration.}

Dominic Bryan

This paper is an exploration, and speculative discussion, of the relationship between ritual acts of commemoration, national and ethnic identities, the discipline of history, and the professional historian. It is built around a number of observations and propositions that together raise questions about the engagement of historians with commemorations for 1916. In short, I want to argue that history has a relationship with ritual commemorative practice which, due to the ideological construction of ritual commemorations, is unlike other academic disciplines. Consequently, the professional historian plays a legitimising role in commemorative practice by endorsing what are acts of political identity. I will make this argument through the following four propositions.

First, whilst commemorative practices appear to be about the past they are actually about the present and the future. Commemorations are a way of capturing the sacrifices of the past to be used in the legitimation of the political present and the imagined political future. Consequently, the nature of contemporary acts of commemoration is better understood by exploring the relationship between identity and contemporary politics than by examining the event being 'remembered'.

Second, the discipline of history plays a role in modern Irish society that has a different status from related subjects in the humanities and the social sciences. Our identities, particularly as imagined communities such as nations, but also ethnic groups, ${ }^{1}$ are invariably built around a historical narrative. As an explanatory tool for understanding 'who we are' history is predominant. Thus, in popular culture, the examination of group identities is usually undertaken by narrative histories. Disciplines such as anthropology, sociology, social psychology, political science and social psychology are better at dealing with the identity questions but in popular discourse they are less often utilised. This status that history has, over and above allied disciplines, is most clearly operative in the school curriculum but is also predominant in the popular media particularly with regards to commemorative practice.

Third, commemorations are conducted by the utilisation of symbols endowed through acts of ritual. To understand how commemorations are controlled we must understand the nature of ritual practice. Rituals appear to defy time by linking participants with the past. ${ }^{2}$ Through culturally

\footnotetext{
${ }^{1}$ Benedict Anderson, Imagined Communities Reflections on the Origins and Spread of Nationalism (London: Verso, 1991)

2 Elizabeth Tonkin and Dominic Bryan, 'Political Ritual: Temporality and Tradition' in Political Ritual (ed) Asa Boholm (Gothenburg : Institute for Advanced Studies in Social Anthropology, 1996) pp.14-36; David Kertzer,
} 
embedded practice the rituals form part of a narrative that imbues groups with a past that suggest they are in communion with those that are being remembered. Indeed, as participants of these rituals are frequently told, 'they died for us'. ${ }^{3}$

My fourth proposition, is that despite my first proposition suggesting the contemporary nature of commemoration, and because of the my second and third arguments suggesting the cultural status of history in identity formation and the role of commemoration in defining contemporary identity, the historian plays a particularly exaggerated role in the arena of commemorative ritual practice. Historians, above all others, are invited onto the media and to the ritual events to comment on the commemorative practice, not because they are the most qualified to do so, if my second premise is right they are not, but because as 'experts' they above all others can legitimise the importance of history in our identity. As such, I conclude that, however noble their role might be as educators of a complex past, they are effectively part of contemporary commemoration and could indeed be seen as the 'high priests' of commemorative practice.

I would like to sustain this argument in the following way. I want to briefly explore the struggle that historians and others have had in Ireland, connected to the 'decade of centenaries', examining the process of memory, remembering and commemorations. Key to this debate is the model of cultural transmission and the role played by commemoration. I will suggest that there are two approaches to the understanding of commemorations: diachronic which explores the ritual through the examination of the past, or where it 'comes from', and synchronic, which examines the present political conditions in which the ritual is constructed. This second approach is the one most favoured through the social sciences and indeed by many historians of commemoration. However, it is counter to the narrative of the commemoration itself and to a popular understanding of the role of history. I will argue that we commemorate because of the nature of group identities, not because of the past. We can clearly see this when we analyse how commemoration is constructed through symbols and rituals. I will particularly examine how rituals of all types defy time and thus give the impression of being in communion with the past. But having constructed a model for commemorative practice and cultural transmission I will look at the role of the historian in the practice of commemoration and suggest that the professional historian should remain very selfaware of their role given the relationship posited through the commemoration of its communion with the past.

David Kertzer, Ritual, Politics and Power (New Haven: Yale University Press, 1988)pp.39-40; Maurice Bloch From Blessing to Violence: History and ideology in the circumcision ritual of the Merina of Madagascar (Cambridge: Cambridge University Press, 1986) p.184.

${ }^{3}$ George Moose, Fallen Soldiers: Reshaping the Memory of the World Wars (Oxford: Oxford University Press 1991) 


\section{Irish History, Remembering and Commemoration}

Irish history has a problem with remembering. The struggle to theorise and conceptualise an understanding of historical memory in the Irish context has been well rehearsed by Beiner (2007, 2014), Frawley (2011) and McBride (2001). ${ }^{4}$ In all three essays a range of theoretical approaches are examined that might, as McBride puts it, 'characterise the relationship between past and present antagonisms'. ${ }^{5}$ McBride goes on to ask whether what we remember is not determined by the past but 'what we chose to remember is dictated by our contemporary concerns'. ${ }^{6}$ This is at the core of my third premise. This possibility is of course well recognised and is at the centre of a Durkeimian approach to the topic proposed by Halbwachs On Collective Memory. ${ }^{7}$

What makes recent memories hang together is not that they are contiguous in time: it is rather they are part of a totality of thoughts common to a group, the group of people we have a relationship with at this moment, or whom we have had a relation on the preceding day or days. $^{8}$

Whilst, as McBride points out, we might worry a little about the emphasis on Durkheimian collective consciousness, ${ }^{9}$ the orientation of this approach is to suggest the present is the construct in which remembering takes place. The question over why such memories are durable ${ }^{10}$ are not answered by the nature of what is remembered but by the durability of social structures and, as I will discuss below, the mechanisms of transmission. McBride sums up this approach by suggesting:

'...remembering and forgetting are social activities, and our images of the past are therefore reliant upon particular vocabularies, values and ideas and representations shared with other members of the present group'. ${ }^{11}$

Keep this idea of 'vocabularies, values and ideas' in mind because I want to argue that the discipline of history plays a key and exaggerated role in this process. For sure, as McBride further argues, the

\footnotetext{
${ }^{4}$ Ian McBride, History and Memory in Modern Ireland (Cambridge: Cambridge University Press, 2001); Guy Beiner, Remembering the Year of the French: Irish Folk History and Social Memory (Madison: The University of Wisconsin Press, 2007); Guy Beiner, 'Probing the boundaries of Irish memory: from postmemory to prememory and back' Irish Historical Studies, Vol. xxxix, no.145, Nov 2014, pp296-37; Oona Frawley, 'Towards a Theory of Cultural Memory in an Irish Postcolonial Context' in Memory Ireland Volume 1: History and Modernity, Oona Frawley (ed) (New York: Syracuse University Press, 2011) pp.18-34.

${ }^{5}$ McBride, History and Memory, p.5

${ }^{6}$ McBride, History and Memory, p. 6

${ }^{7}$ Maurice Halbwachs, On Collective Memory (Chicago: The University of Chicago Press, 1992).

${ }^{8}$ Halbawchs, On Collective Memory, p.52

${ }^{9}$ McBride, History and Memory, p.7

${ }^{10}$ McBride, History and Memory, p.8

${ }^{11}$ McBride, History and Memory, p. 12
} 
present is in 'complex interaction' ${ }^{12}$ with materials from the past available but I would argue the construction of the past is present oriented.

So what of the conceptual framework of memory, remembering and commemoration that much of the debate takes place in? The arena of memory studies or social memory or collective memory, or, as Frawley and others have more usefully termed it, 'cultural memory', ${ }^{13}$ has been a rapidly expanding field. ${ }^{14}$ I do not intend to review it here because I want to concentrate on commemoration, which is a particular aspect of the field. But it is important to understand the difficulties in using various models of memory in relation to historical studies. In a series of exciting books and essays Beiner experimented with models of memory transmission and their relationship with historical study. In a later essay he has identified process of postmemory and prememory as part of a model of memory 'as an open-sided series of recycled representations'. ${ }^{15}$ Originally suggested by Hirsch, postmemory is that which takes place in future generations and is thus delayed and indirect. ${ }^{16}$ This is the arena for many of the studies on commemoration and tradition. ${ }^{17}$ However, Beiner and others identify processes called prememory referring to the ways in which, even as an event is taking place, it is being 'understood and interpreted through reference to memories of previous events' and 'traditions of prememory shape and influence the subsequent memory of the event' ${ }^{18}$ An example of this might be the reception of the Battle of the Somme amongst Protestants in the north of Ireland constructing the memory of the event through a preexisting set of events captured within Orangeism. ${ }^{19}$

One of the ongoing tensions in the sort of models discussed by Beiner and Frawley is the relationship between social memory and the biology of individual memory. Frawley tackles this head on by examining cognitive theories of memory utilising Whitehouse and suggesting that ideology and political organisation might be derived from universal feature of human memory rather than the other way around. ${ }^{20}$ Frawley goes on to discuss the impact this might have on narratives in the construction of cultural memory ${ }^{21}$ but recognises 'the formidable power of cultural imperatives to

\footnotetext{
12 McBride, History and Memory, p.13

${ }^{13}$ Frawley, Memory Ireland Vol.1, pp.xiii-xxiv

${ }^{14}$ Barbara Misztal, Theories of Social Remembering, (Berkshire: Open University Press, 2003).

${ }^{15}$ Beiner, 'Probing the boundaries of Irish memory', pp304

${ }^{16}$ Marianne Hirch in Beiner, 'Probing the boundaries of Irish memory', pp298-299.

${ }^{17}$ Most obviously in Eric Hobsbawm and Terence Ranger, The Invention of Tradition (Cambridge: Cambridge University Press).

${ }^{18}$ Beiner, 'Probing the boundaries of Irish memory', p.300

${ }_{19}$ Dominic Bryan, 'Forget 1690, Remember the Somme', in Memory Ireland Volume 3: The Famine and the Troubles Oona, Frawley (ed) (New York: Syracuse University Press, 2014) pp.293-309.

${ }^{20}$ Frawley, Memory Ireland Vol.1, p.22-23, quoting Harvey Whitehouse (2000) Arguments and Icons: Divergent Modes of Religiosity Oxford: Oxford University Press pp5-9.

${ }^{21}$ Frawley, Memory Ireland Vol.1, pp24-26.
} 
persist and to be shaped by the circumstances of culture' recognising also that 'cultural memory is fluid and processual'. ${ }^{22}$

The attempt to provide conceptual frameworks for remembering has been considerably influenced in Ireland by what has been called the decade of commemorations. This period, running from around 2012 to 2022, covers what are understandably deemed to be vitally important events in contemporary Irish history. However, although important they maybe, they conveniently take the events just out of living memory, and are no more or less important 100 years on, unless the commemorative practices makes this so. Their importance only varies because we choose, in a rather arbitrary manner, to decide that the centenary of these events is somehow important. Quinault has identified the 'cult of the centenary, c1784-1914' and suggested, much as Hobsbawm and Ranger examined the invention of tradition, as period of centenary production. ${ }^{23}$ And we consider this to be true because there is a political context in the present which makes them important. In other words, they provide symbolic (or political) capital to a range of contemporary agents. Their influence is largely dictated by the power structures of the social field in the present, not the past. ${ }^{24}$ As such, to understand memory, remembering and commemorative practice we need to have a clearer model of cultural transmission. Central to that understanding must be a present day oriented research model. In other words, what are the synchronic factors that influence the remembering and commemorative processes and how are they transmitted. Why and how are historic events reproduced in the present?

If we take this position then the model of memory and remembering becomes secondary. Commemorations are not about the past they are about the present. And they are not about memory, they are about identity. I want to be clear that there is plenty of historical practice that critically understands this position. Take the corpus of research that has been undertaken on the fiftieth anniversary of the 1916 Rising. ${ }^{25}$ In a telling couple of lines Higgins identifies what dictates the commemorative in the Ireland of 1966.

The commemoration was driven by two forces which gained in significance as the commemoration approached: to demonstrate the success of the modern Republic and to

\footnotetext{
${ }^{22}$ Frawley, Memory Ireland Vol.1, p34

${ }^{23}$ R. Quinault (1998) 'The Cult of the Centenary c.1784-1914', Historical Research, 71 (176), pp. 303-323. Hobsbawn and Ranger, The Invention of Tradition.

${ }^{24}$ Pierre Bourdieu, In Other Words: Essays Towards a Reflexive Sociology (Stanford: Stanford University Press, 1990) p.135.

${ }^{25}$ Mary Daly and Margaret O'Callaghan (eds), 1916 in 1966: Commemorating the Easter Rising (Dublin: Royal Irish Academy, 2007); Rosin Higgins, Transforming 1916 : Meaning Memory and the Fiftieth Anniversary of the Easter Rising Cork: Cork University Press (2012)
} 
sideline the republican movement (as the IRA and its environs were referred to in the late 1960s). ${ }^{26}$

Commemoration is driven not by memory but by the politics of the present. ${ }^{27}$ Indeed it is vital to the politics of ritual commemoration that the concepts of memory (and sometimes tradition) are used to disguise what is taking place because they give the impression that legitimacy is gained from the past. Historians, in their understandable enthusiasm to educate people of their history provide ideological cover for politics and power. History, when reproduced within the ambit of commemorative ritual, risks not being revelatory or educational but a disguise for relationships of power.

\section{Identity, Ritual and Ethno-nationalism: An Alternative model for Commemoration}

There is alternative model for examining the cultural processes in which 'memory' plays a more minor role. Commemoration frequently appears in ritual form created in the present by actors as an expression of their identity. It is a reflection of a group identity that could be local, institutional, ethnic or national. The ability to apparently transmit the past into the present is part of the function of the ritual. In commemoration the ritual is, almost by definition, endowed with symbols and a narrative that appear to create a communion with the past, and yet it is created in the present and is chiefly about identity and is a comment on the present and the future.

Let me return to the basic problem. In trying to analyse this impact the past has on the present we are struggling with transmission, or more broadly still, change and continuity in society. This is a problem at the heart of sociology and anthropology. Indeed, it is interesting if we look at the intellectual history of the discipline of anthropology it also resorts to evolutionary or what are effectively historical answers. In the nineteenth century prior to the full impact and Durkheimian sociology, anthropologists attempted to understand social institutions by tracing their evolutionary routes. We attempted to examine cultural traits and social institutions by tracing some sort of origin, whereby they were brought into existence and then handed down. The key theoretical change that effectively solved this problem, or at least provided an alternative perspective, was the functionalist turn in the social sciences. This theoretical shift was chiefly introduced through Durkheimian sociology which In British Social Anthropology became known as structural functionalism. ${ }^{28}$ One of its key messages was that to understand the existence of various social institutions you needed to

\footnotetext{
${ }^{26}$ Higgins, Transforming 1916, p3

${ }^{27}$ See D. Berliner (2005), 'Social Thought and Commentary: The Abuses of Memory: Reflections on the Memory Boom in Anthropology', Anthropology Quarterly, 78 (1), pp. 197-211

${ }^{28}$ Marvin Harris, The Rise of Anthropological Theory: A History of Theories of Culture (London: Routledge and Kegan Paul, 1969), pp514-519.
} 
analyse how they worked in the present, in other words how they functioned, rather than concentrate on how they evolved out of the past. This created a synchronic turn in the anthropological analysis of society. Rather than trace the evolution of an institution through types of historical or archaeological constructions you conducted fieldwork in the present to see how that institution played a part in present day society. The answer as to why a social or cultural trait exists lies in the present not in the past. This meant examining the social relationships, or social structure, that existed in society and suggested a quite different methodology. This is true of a commemorative ritual just as much as it is true of rites of passage or cultural artefacts. As I will make clear, we are not ignoring history but we are suggesting that it has reduced importance as an explanatory tool for understanding commemoration.

If we return then to the problem of transmission of historical events, to the issue of how and why remembering takes places, then this synchronic, rather than diachronic approach, offers us another type of answer. Instead of looking for mechanisms that somehow push this past into the present, we examine why the social relationships of the present reproduce the past. We end up examining what might be called pull factors for transmission, not push factors. What we need to examine, in many ways, holds little relation to what happened in the past but is explained by the social relationships of the present.

A key mechanism, although clearly not the only mechanism, through which this process is managed, is ritual. Theorised heavily in anthropology, ritual provides us with a clear mechanism of transmission that is not really about memory, or rather does not necessitate the mechanism of memory as central. There are of course lots of arguments about the nature of ritual and how it might be defined but there exists a broad model around the type of social practice that is repetitive, rule bound, existing as a discrete social activity and, importantly, laden with symbolic practice and great potential emotional power. ${ }^{29}$ They are thus important as rites of group cohesion, or as Victor Turner would phrase it communitas. ${ }^{30}$ The ritual provides a potential moment of social cohesion, or, to return to Durkheim, ritual provides 'effervesence'. In Elementary Forms of the Religious Life he argues

There can be no society which does not feel the need of upholding and reaffirming at regular intervals the collective sentiments and collective ideas which makes its unity and its personality. Now this moral remaking cannot be achieved except by the means of reunions, assemblies and meetings where the individual, being closely united to one another, reaffirm

\footnotetext{
${ }^{29}$ Catherine Bell, Ritual Theory, Ritual Practice (Oxford: Oxford University Press, 1992); Ronald L. Grimes, The Craft of Ritual Studies (Oxford: Oxford University Press); Kertzer, Ritual, Politics and Power.

${ }^{30}$ Victor Turner, The Ritual Process (Chicago: Aldine, 1969).
} 
in common their common sentiments; hence come ceremonies which do not differ from regular religious ceremonies, either in their object, the results they produce, or the processes employed to attain these results. ${ }^{31}$

But ritual does more than simply reflect some broad set of social values. It utilises, in part through the use of symbols, what that social group might have in common even if that group or society is riven with conflict and difference. As Victor Turner puts it ' $(A)$ society continually threatened with disintegration is continually performing reintegrative ritual'. ${ }^{32}$ And as David Kertzer points out in Ritual, Politics and Power, effectively the manual for anthropological approaches to ritual, the beauty of this approach is it captures the psychological needs of individuals and explains how individuals' actions are converted into the social. ${ }^{33}$

Ritual then can creates solidarity without consensus. ${ }^{34}$ It does this in a number of ways, but of particular interest to my argument is the way that symbols work within the ritual. Symbols of course provide a resources for meaning but, and this is important, they cannot be read simply as a text. It is participants in the ritual that provide symbols with meaning and whilst they may share allegiance with those symbols they do not need to share the same meaning. Symbols are usefully ambiguous. Anthony Cohen argues that they create 'the symbolic construction of community'. ${ }^{35}$ And this, in turn, can be linked to the broad theory of nationalism proposed by Benedict Anderson that the modern nation is an imagined community. ${ }^{36}$ In part, maybe in large part, this community is imagined through rituals and symbols.

There is, however, another aspect to this model that should be put in place before we examine the nation. The relationship that a person shares with the different social groups they participate in is governed by identity. Identity is important because it builds a sense of self, who we believe we are, but it does so in relation to other people, the social groups around us and the physical environment. Of significance is not only the groups that we believe we are part of but also the groups that we are not in. The social psychologists refer to groups as in-groups and out-groups. Tajfeld argued that this was the basis of pride and esteem. ${ }^{37}$ It is the basis of our relation to others, of the way we present

\footnotetext{
${ }^{31}$ Emile Durkeim, The Elementary Forms of the Religious Life (London: George Allen and Unwin, 1915) p.427, see also Kertzer Ritual Politics and Power p.62.

32 Victor Turner, Schism and Continuity in an African Society (Manchester: Manchester University Press, 1957) p.303.

${ }^{33}$ Kertzer Ritual Politics and Power, p.63

${ }^{34}$ Kertzer Ritual Politics and Power, p.67.

${ }^{35}$ Anthony Cohen, The Symbolic Construction of Community (London: Tavistock, 1985).

${ }^{36}$ Benedict Anderson, Imagined Communities

${ }^{37} \mathrm{Hnri}$ Tajfeld (Ed.) Differentiation between social groups: Studies in the social psychology of intergroup relations. (London: Academic Press, 1978)
} 
ourselves and interact with others, and how we judge who we are as an individual against the groups we are part of. It is the link between the individual and the social. Most significantly for my purposes 'the meanings associated with any social identity are products of our collective history and present. ${ }^{38}$ To immediately link that to participation in a generalised notion of commemoration we can see the power of such an event. To honour the fallen heroes of the social group that we believe we are part of is a huge statement. It is one of pride but also of potential social distinction and provides a narrative for our social group. It is a powerful statement of legitimation of who we are. On top of all this it is usually highly gendered, almost always making statements about maleness and femaleness and identifies our relationship with out groups, sometimes known as 'perpetrators' or 'enemies'. The individual acts of commemoration are also, of course, wrapped up in memories and narratives connected to the self but crucially they potentially provide social, public, recognition of those narratives.

In the contemporary world we are members of a range of groups and therefore our sense of self can shift across a range of identities depending upon context. However, of all our potential groups, perhaps the most powerful are the imagined communities of ethnicity and nationhood. ${ }^{39}$ In creating these imagined communities of ethnic group and nation it is crucial that a link is made with the past, that there is a historical narrative about who we are and why. Politically, to glue these social groups together, the most powerful claim is that our 'forefathers', and note here 'forefathers', sacrificed themselves in the name of the group and that they need to be honoured and respected.

The events or figures marked in commemoration are inextricably symbolically linked to the 'history' of the state/nation/ethnic group as a 'myth of origin'. Thus the politics of memory is intimately bound to the politics of identity. ${ }^{40}$

Consequently, such an ideologically powerful claim is used by politicians all the time to engender group cohesion and potential social action. Thus the sacrifice of the past should remind us how to behave in the present or the future. It invokes a debt to be paid. And what could be more powerful than the debt to those that gave up their lives. As such, we are told, we must remember them. The 'them' is very often people of whom we have no memory and who, particularly after a generation, have no voice independent of the words and deeds they left us before they died, but which we, and particularly those with power, can reinterpret. By remembering them we can appropriate their

\footnotetext{
${ }^{38}$ Stephen Reicher, Russell Spears, S. Alexander Haslam, 'The Social Identity Approach in Social Psychology' In M. S. Wetherell \& C. T. Mohanty (Eds.) The Sage Identities Handbook. (London: Sage, 2010 ) pp45-62.

${ }^{39}$ See Richard Jenkins, Rethinking Ethnicity: Arguments and Explorations (London Sage, 1997); Thomas Hylland Eriksen Ethnicity and Nationalism: Anthropological Perspectives (London; Pluto 1993).

${ }^{40}$ Rebecca Graff-McCrae Remembering and Forgetting 1916: Commemoration and Conflict in Post-Peace

Process Ireland (Dublin: Irish Academic Press,2010) p.7.
} 
sacrifice into present day politics. And what better to legitimise that claim than the presence of a professional historian. But I am getting ahead of myself.

Social groups are of course complex. Not everyone feels the same way about their relationship with particularly groups that they may be a part of. People have individual identities. As such, people do not all interact with commemoration in the same way. As discussed above, rituals allow people to participate in common events without necessarily sharing the same meaning or narrative.

Nevertheless they offer apparent common belonging. But even more powerfully, and by powerfully I of course mean politically, a claim can be made on outlying members of the group who may feel resistance to the activities of the national and/or ethnic group. As such, ritual and symbolic activities are constructed that make people, even force people, to either show respect to the past, and thus endorse a particular understanding of the present, or take the difficult step of dissenting and thus risk the accusation of not respecting the dead. Consequently, commemorative practice is also a boundary marker in the sense that Fredrick Barth describes in his classic exposition of the nature of ethnic groups. ${ }^{41}$

'The critical focus of the investigation from this point of view becomes the ethnic boundary the defines the group, not the cultural stuff that it encloses' ${ }^{42}$

Thus commemorative rituals of republican and loyalist in Northern Ireland share much in common in terms of cultural background and the organisation and ideology of practice. The lily and the poppy are boundary makers and therefore frequently part of dispute, debate and negotiation.

Whilst clearly commemorative practice exists across a range of different types of groups, of particular interest here are the boundaries of ethnic and national groups. The longevity of the social groups we called nations are still a matter of dispute, however, I am clearly taking the position of a large number of theorists that, despite nationalists arguing that their particular nation has historical roots that go back centuries, the form of the nation that is now globally dominant took shape in the eighteenth century reaching some of it first full expression with the French and American revolutions. Without now participating in the debates about how and why this happened Anderson, Hobsbawm and Gellner, to name three key theorists, remain important in articulating this argument for the instrumental rather than primordial view of the nation. ${ }^{43} \mathrm{It}$ is interesting that in elucidating

\footnotetext{
${ }^{41}$ Fredrick Barth Ethnic Groups and Boundaries: The Social Organisation of Cultural Difference (Illinois: Waveland Press, 1969, reissued 1998).

${ }^{42}$ Barth 1969 Ethnic Groups and Boundaries pp.15

${ }^{43}$ Anderson, Imagined Communities; Ernest Gellner, Nations and Nationalism (Oxford: Basil Blackwell, 1983); Eric Hobsbawm, Nations and Nationalism since 1780: Programme, Myth, Reality (Cambridge: Cambridge University Press, 1990).
} 
his argument for the nation as an imagined community, 'imagined because members of even the smallest nation will never know most of their fellow members... yet in the minds of each lives the image of their communion', ${ }^{44}$ Anderson starts with the question of why those who are part of this fraternity of the nation, 'conceived as a deep, horizontal comradeship', over the past two centuries, are 'willing to die for such limited imaginings.' ${ }^{45}$ And his answer starts with the suggestion that there is 'no more arresting emblems of the modern culture of nationalism than cenotaphs and the tomb of the Unknown Soldier'. ${ }^{46}$

Yet void as these tombs are of identifiable mortal remains or immortal souls, they are nonetheless saturates with ghostly national imaginings'. ${ }^{47}$

Crucial to the idea of a nation is that it exists, as a community, over time. And no more powerful element of that image exists than the idea that members of that community sacrificed themselves for the community.

On the construction of the nation, and returning to the differences between history and anthropology with which I started this section, Erikson perceptively notes that 'whilst most historians tend to try to find out what really happened - some even distinguishing between 'invented' traditions and 'real' traditions - most anthropologists would rather concentrate on showing ways in which particular historical accounts are used as tools in the contemporary creation of ideas and in politics'. ${ }^{48}$ Reicher and Hopkins point out that 'whether nations are recent or ancient is not the point, what counts is that they are always imagined as ancient.. ${ }^{49}$ And the key site for these 'historical imaginings' are rituals. And the most powerful of these are surely commemorative rituals. As is understood generally with the symbolic construction of community, ritual provides an opportunity for common involvement by potentially diverse groups which may not, indeed very likely will not, share the same understanding of participation. Thus those involved may construct different narratives from the event yet still share participation. Those with power within the ritual however are better able to utilise the symbolic capital. These social institutions are thus particular sites for social relationships imbued with power ${ }^{50}$. Rituals are important in the creation, maintenance and negotiation of political legitimacy. Perhaps the most important way they do this is to offer a sense of continuity over time and therefore a powerful potential to create a communitas

\footnotetext{
${ }^{44}$ Anderson, Imagined Communities; p.6

${ }^{45}$ Anderson, Imagined Communities p.7

${ }^{46}$ Anderson, Imagined Communities p.9

${ }^{47}$ Anderson, Imagined Communities p.9

${ }^{48}$ Erikson Ethnicity Nation and Nationalism: p.71-72.

${ }^{49}$ Stephen Reicher and Nick Hopkins Self and Nation (London: Sage, 2001) p.17

${ }^{50}$ Kertzer Ritual Politics and Power pp.174-185.
} 
with the past. ${ }^{51}$ They are frequently central to 'tradition' and also at the heart of commemorative practice. They are beloved research sites for anthropologists and political scientists as they reveal both the nature of key social relationships in a society but also the narratives of legitimacy that accompany those social relationships.

Rituals are therefore the mechanism by which synchronic social relationships, the political relationships of the present, are converted, ideologically, into a communion with the past. These rituals take place in public spaces with specific roles associated with people with power and a narrative which they will attempt to define.

The ritual therefore acts as a form of cultural transmission capable of being taught and re-taught. Although it appears to give continuity over time, it is constructed and reconstructed in the present. Each rehearsal of the ritual is unique. Continuity is not provided by some memory over time but by the existence of a set of social relationships over time.

...rituals are recognised as such because they are recognisable as formalised events, and thus by inference they are repetitive. Yet they can also be recognised as events thus by inference they include actions. They are symbolic and at once both repetitive and unique. ${ }^{52}$

It is the social structure where continuity, discontinuity and contest are played out. Weakly propositional, but potentially highly emotional, commemoration rituals allow potential contestation but political power also offers dominant political narratives an advantage. As such, the important public spaces and the key moments in time are held and controlled by those in power. Those contesting those narratives need to look for alternative spaces or times through which to utilise the potential symbolic capital available through commemorative union with the past.

I would go further and argue that even when events look like they have continuity, that the rituals have not changed over time (although usually close examination reveals they have), that it is likely that those using these legitimatising events have changed. In other words the ritual and the symbols might remain fixed even through the social relationships have altered. ${ }^{53}$ Crucial to the process are the contemporary relationship of politics and power. Or to put it another way, the key factors for remembering and commemoration are synchronic not diachronic. Any analysis of transmission must start with the contemporary period. What is being remembered is relatively unimportant; it is why and how that is crucial. As social relationships of power have continuity, transmission can be

\footnotetext{
${ }^{51}$ Tonkin and Bryan, 'Political Ritual' pp.14-36; Bloch From Blessing to Violence p.184.

52 Tonkin and Bryan 'Political Ritual' pp14-15

${ }^{53}$ Dominic Bryan, Orange Parades: The Politics of Ritual, Tradition and Control (London: Pluto Press, 2000) pp.19-22.
} 
partially assured. The reasons for transmission lie not in the past but in the relationships of power in the present. Those relationships are negotiated with acts of resistance appearing through tension in those power relationships. ${ }^{54}$ It is the job of the anthropologist and historian to map these relationships.

Commemorations given a synchronic rather than diachronic analysis are much more explicable. My suggestions is that if we take this approach, which let me be clear again many historian effectively do, then our problems of transmission become easier to solve. Roisin Higgins, a historian, does exactly this in her work on the commemoration of 1916 in $1966 .{ }^{55} \mathrm{I}$ also think that hazy mechanism such as 'memory' and 'trauma' can be analysed in a quite different way, as part of the narrative, and do not need to bare the explanatory weight that makes them look so problematic. And activities such as commemoration given a synchronic rather than diachronic analysis are much more explicable.

Ritual is, of course, not the only form a transmission. There are many other mechanisms ranging from formal history through to oral histories, via varieties of archives; from sites of memory such as memorials through to individual memories. And it is important that the historian's relationship to these other forms such as museums and archives is potentially different to that of ritual. But regardless of the mechanism, all of these forms of transmission rely on construction and interpretation in the present. The past may be transmitted through a variety of mechanisms but the important aspect of the interpretation of that past are the social relationships of the present. Out of these arise dominant narratives, dominant ideologies, and whilst we can find alternatives fostered in parts of society, and whilst contestation might be taking place, they will only prosper if social relationships are changing.

\section{What is the relationship between historian and commemoration?}

Commemoration, therefore, is not determined by the calendar. It is a matter of choice. It is not essentially about history - it is about culture. It is about ideas of the 'historic' that are always shaped by the present-day concerns and power structures. ${ }^{56}$

If the model I have described, which, despite a few key debates, would I think be broadly accepted across the political and social sciences, then it raises the issue of the role of historians. As Fintan

\footnotetext{
${ }^{54}$ Bryan, Orange Parades.

${ }^{55}$ Higgins, Transforming 1916.

${ }^{56}$ Fintan O'Toole (2013) 'Beyond Amnesia and Piety' in Towards Commemoration: Ireland in War and Revolution 1912-1923 eds. John Horne and Edward Madigan Dublin: Royal Irish Academy p.155
} 
O'Toole asks 'what should historians have to do with any of this?' ${ }^{57}$ Well, judging by their involvement on committees and on also sorts of media connected the Irish decade of centenary, the answer seems to be: quite a lot. For major events, the attempt to provide a narrative will be done using the mass media. As such TV, Radio the press and online will be searching for historians of the historical moment to be remembered in order to discuss what is taking place. Local councils, government agencies, community groups, documentary makers search for the historian that might tell us why the commemoration is taking place and why it is important. In contrast, the social and political scientists are much more rarely seen. And yet, if I am right, they are the people who can better explain commemoration.

Let me make some observations about the discipline of history, then look at the relationship of the historian to commemoration, before, some might be relieved to hear, discussing why history is important. Without judging the value of different disciplines there seems to be a hierarchy within our society, particularly pertinent at schools. History has a place in our society that is unlike other disciplines in the social and political sciences because it has a role in nationalism unlike other disciplines. It has a place in our schools unlike the other social and political sciences. It has a place on the TV channels unlike those other disciplines. It has a place in popular Irish culture unlike any of those other disciplines, except, maybe, a popular version of psychology. In terms of understanding 'who we are', history, apparently, provides the answer. And there is an obvious reason for this. As already discussed, we live as part of nations and states that legitimise themselves through historical narrative. Jenkins suggest that a key components of nationalism is the 'appeal to the past - an ethnic-national history embodied in such things as myths of origin, royal genealogies or cultural romanticism - in a construction of a collective project for the future'. ${ }^{58}$ Jenkins and Benedict Anderson are attracted to the powerful imagery of Walter Benjamin's 'angel of history ', as Jenkins puts it 'looking back, in nostalgia and anger, but irresistibly propelled forward at the mercy of progress. ${ }^{59}$ This rather dark view of nationalism might be countered with examples of civic nationalism and a more nuanced view would be necessary in a longer argument. Nevertheless, the role of history as a discipline for nationalism is very specific and, of course, historians have played, and continue to play, a full part in the creation of the national story. Whilst this is sometimes to create complexity and myth busting, as well as, in the case of historians such as Hobsbawm, ${ }^{60}$ the critical ideas to examine the inventing of nationalist traditions, popular history is the core of nationalist ideological constructions. History has a relationship to nationalism not dissimilar to the

\footnotetext{
57 O'Toole p.155

58 Jenkins Rethinking Ethnicity p.162

59 Jenkins Rethinking Ethnicity p.162; Anderson Imagined Communities p.147.

${ }^{60}$ Hobsbawn Invention of Tradition.
} 
relationship biology has to 'race'. As I have described elsewhere, I have always been struck by the claim, particularly amongst people in working class Protestant groups in Northern Ireland, that young people need to learn their history so that they can know their identity. ${ }^{61}$

The position that the discipline of history has within our society and particularly or education system is important. Because, whilst history is good at teaching about the nation, it is less good at theorising about nationalism. And those disciplines that might offer such critical tools - sociology, anthropology, political science - are much less frequently taught, certainly to children under the age of 16 . And subjects such as social psychology and anthropology that might develop critical tools around identity and virtually absent from the school curriculum.

In addition, the idea that our identity, who we are, can be defined through what we are told is 'our history' is a powerful idea on the media. We are told where we have come from and who we through a historical narrative. And whilst I am absolutely not denying the importance of understanding a history from many perspectives, and as a vital part of learning what it is to be human, the discipline of history has an elevated status next to those other disciplines. In popular culture, regardless of the more nuanced world of academic history, when the people want to know what their identity is, they turn to historian.

Unsurprisingly then, but I would suggest problematically, when the decade of centenaries approaches, to understand why they might be commemorated and what is being commemorated, he media and policy makers turn to the historian. And thus we are left with the strange contradiction. Whilst the critical tools for understanding the processes of commemoration are provided by the political and social scientists it is the historians that are invited to mould and comment on the events. And of course they would be. Because the whole rational of the commemoration is that history is important, that the past legitimises who we are, that we are in communion with the people that went before us. As such, the very presence of the historian, even the historian out to myth bust and critically analyse what is taking place, actually legitimises the practice. Historians are the high priests of the commemorative rituals. As commentators and advisors they are also participants. And, with notable exceptions, the historian is unlikely to suggest that today's commemoration has little to do with the events of the past and everything to do with political identity.

I want to be clear about a couple of aspects of this process lest my analysis is mistaken simply as an attack on the discipline and on historians. First, I fully appreciate that the periods of commemoration

\footnotetext{
${ }^{61}$ Dominic Bryan 'The Politics of Community', Critical Review of International Social and Political Philosophy Vol. 9, No. 4, 603-617, December 2006.
} 
provide historians with spaces of potential public education and they understandably jump at this opportunity. It is an arena for public history. My issue is not with good education through history teaching from good critically engaged historians. Indeed, it is vital. However, I am suggesting that a period of commemoration is problematic for that process precisely because the commemorative practice is first and foremost and exposition if public identity. The apparent educational opportunity is also a reaffirmation of a particular political identity to which the historian, of all 'experts' is likely to provide legitimacy. Second, there is a role for the historian to present more complex pictures of our past and that this does make the commemorative space a potentially critical and negotiated space. Indeed, there is an argument that it would be worse for historians not to get involved. In other words, I can see the potential for change through engagement. However, I think change is far more likely to be driven by alterations in the fundamental social and power relationship in society then through some realisation or consciousness raising about the nature of the past. And the historian does provide legitimacy to the ritual just by their presence. Third, and most importantly, there are historians of commemoration who are not only vital in understanding these processes but have been, and are, critical in understanding the reproduction of the past in the present. Central to the argument I am making is the need to for historical analysis of commemorative practice. ${ }^{62}$ However, I am suggesting that that the role of the discipline of history in both the practices of commemorations and in the understanding of memory and remembering is problematic as it lacks the conceptual tools for the task. It therefore profiles particular types of transmission over others thereby, frequently, disguises the necessary, and fundamentally, a synchronic process.

\section{Conclusion}

'History and commemoration are not incompatible, but the proper relationship between these two pursuits is contested and uneasy ${ }^{\prime 63}$

Let me finish with 1916 and dramatic Easter events in Dublin and on fields of Flanders. Both made a massive and traumatic impression upon those that survived. In both cases practices of commemoration began almost immediately driven in part by the psychological needs of survivors and people into the society they entered back into. But from those moments on, commemorative practice was defined not by what took place but by the social and political relationships that then existed. The relatively small military excursion in Dublin and the executions that followed were to be constructed through social relationships that turned a handful of Irish rebels into martyrs and

\footnotetext{
62 Daly and O'Callaghan 1916 in 1966: Rosin Higgins, Transforming 1916.

63 David Fitzpatrick 'Historian and the Commemoration of Irish Conflicts, 1912-23' p.126 in Towards Commemoration: Ireland in War and Revolution 1912-1923 ed John Horne and Edward Madigan Dublin: Royal Irish Academy
} 
founders of a new country. The Irishmen that died at the battles of the First World War, such as those at Suvla Bay during the Dardanelles Campaign, were destined for a much lower profile until political relationships in the next century were to determine their symbolic capital would rise again. ${ }^{64}$ Just as the destiny of the remembering of the Australians that died at Gallipoli, in that same Dardanelles campaign were to come to be seen as the founders of a proper independent nation at the southern end of the Pacific Ocean. ${ }^{65}$

These historical events are areas for negotiation and dispute amongst historians and others. But we must distinguish different types of contestation. There may well be a variety of interpretations of the past events, however, the more significant form of contestation, less often discussed are the political relationships of the present, the synchronic social relationships, within which the construction of the commemoration is taking place. ${ }^{66}$ For these commemorations are not first and foremost about the past, they are about the present and the future. They are a function of contemporary political relationships as well as a potential mechanism to create change in the social relationships. It is precisely these relationships that reproduce historical events into the present, legitimised as acts of 'remembering' and of memory. The danger of using commemoration as a moment for historical engagement is that you collude with a statement of political identity, legitimising and possibly disguising the politics of the present with the cloak of the past. And whilst it is understandable that historians feel it is important to use the commemorative space to complicate our understanding of the past, or to myth bust, they are dealing with powerful, possibly the most powerful, types of claims that nationalism makes. Rather than myth bust they might simply be legitimising the political claims by appearing as the 'high priest' of the past.

I have suggested that the discipline of history has a problematic role in analysing this process because it provides much of the material for a more diachronic understanding of practice. It does this by continually highlighting the importance of the historical events themselves, thus disguising the contemporary political context. In other words, it tends to suggest that we remember 1916 because of 1916 not because of 2016. The historians, often through a claim to 'bust myths', thus become part of the disguise process giving legitimacy to contemporary political actors. Second, that an analysis of the mechanisms of transmission reveal how the contemporary actors control the narratives largely dictated by the use of commemorative rituals. Rituals become the mechanism with

\footnotetext{
64 Dominic Bryan and Stuart Ward "The Deficit of Remembrance': The Great War Revival in Australia and Ireland' in Exhuming Passions: The Pressure of the Past in Ireland and Australia, Katie Holmes and Stuart Ward (eds) (Dublin: Irish Academic Press, 2011) pp163-186.

65 Bryan and Ward, The Deficit of Remembering.

${ }^{66}$ See particularly Graff-McCrae Remembering and Forgetting 1916; Elisabetta Viggiani, Talking Stones: The Politics of Memorialisation in Post-Conflict Northern Ireland (Oxford: Berghahn Books, 2014).
} 
which synchronic political factors are 'converted' into diachronic claims of legitimacy. The provision of an expert historian in the popular, media-driven, production of commemorative practice, and the use of historians where acts of remembering are understood through the concept of memory, give symbolic capital to the acts of political practice. At every commemorative occasion the newspapers, TV and radio studios are populated by historians who, with some exceptions, are usually historians of the period(s) being commemorated. The historians may be there for very noble reasons, however, if my argument about the synchronic nature of remembrance practices is correct, what they are doing is embellishing the symbolic capital, the legitimacy, of the rituals. It is a complex form of legitimacy as historians are undoubtedly engaged in critical debate over the historical events, nevertheless it still serves to provide a diachronic form legitimacy to commemoration to essentially synchronic political practice. 